\title{
Spatio-temporal patterns of extreme fires in Amazonian forests
}

\author{
Ana Cano-Crespo ${ }^{1,2, a}$, Dominik Traxl $^{3}$, and Kirsten Thonicke ${ }^{1}$ \\ 1 Potsdam Institute for Climate Impact Research, Potsdam, Germany \\ 2 Geography Department, Humboldt University of Berlin, Berlin, Germany \\ 3 Institute of Earth and Environmental Science, University of Potsdam, Potsdam, Germany
}

Received 29 November 2020 / Accepted 23 April 2021 / Published online 24 June 2021 (C) The Author(s) 2021

\begin{abstract}
Fires are a fundamental part of the Earth System. In the last decades, they have been altering ecosystem structure, biogeochemical cycles and atmospheric composition with unprecedented rapidity. In this study, we implement a complex networks-based methodology to track individual fires over space and time. We focus on extreme fires - the $5 \%$ most intense fires - in the tropical forests of the Brazilian Legal Amazon over the period 2002-2019. We analyse the interannual variability in the number and spatial patterns of extreme forest fires in years with diverse climatic conditions and anthropogenic pressure to examine potential synergies between climate and anthropogenic drivers. We observe that major droughts, that increase forest flammability, co-occur with high extreme fire years but also that it is fundamental to consider anthropogenic activities to understand the distribution of extreme fires. Deforestation fires, fires escaping from managed lands, and other types of forest degradation and fragmentation provide the ignition sources for fires to ignite in the forests. We find that all extreme forest fires identified are located within a $0.5-\mathrm{km}$ distance from forest edges, and up to $56 \%$ of them are within a 1-km distance from roads (which increases to $73 \%$ within $5 \mathrm{~km}$ ), showing a strong correlation that defines spatial patterns of extreme fires.
\end{abstract}

\section{Introduction}

Fire is an Earth system process that has been shaping vegetation dynamics and influencing atmospheric composition for millions of years. Humans have been using fire to manage the landscape for millennia [1-3]. Centuries of experience in managing fuel to lower fire risk and maintain a diverse landscape is captured in traditional and often indigenous knowledge in many tropical semi-arid regions, such as African savannas, Australia or the Brazilian cerrado $[4,5]$. However, over the past decades fires have often been used as a cheap tool in deforesting tropical forests, which are not adapted to fires and undergo significant alterations in composition, structure and functions [6,7]. In the Brazilian Legal Amazon (BLA), about $4600 \mathrm{~km}^{2}$ of forest were lost to deforestation in low (2012) and up to $27800 \mathrm{~km}^{2}$ in high (2004) deforestation years [8]. The establishment and enforcement of the Action Plan to Prevent and Control Deforestation in the Brazilian Legal Amazon (PPCDAm) in 2004, together with the Soy Moratorium in 2006, and the Zero-Deforestation Cattle Agreements in 2009 allowed to progressively reduce deforestation rates from 2005 onwards [9, 10]. While the use of fire in deforestation was an accepted paradigm for a long time, Aragão et al. [11] suggested a decoupling

\footnotetext{
${ }^{a}$ e-mail: canocrespoana@gmail.com (corresponding author)
}

between deforestation and fire because the decrease in fire activity was not as strong as the decline in deforestation during the period 2003-2015. However, Libonati et al. [12] revisited the decoupling hypothesis recently and found a much weaker decoupling for the same period, which consequently reinforces the role of deforestation as a major driver of fire in Amazonia. Management fires that escaped from agricultural lands and cattle pastures in previously deforested areas into the surrounding forests became the largest driver of forest burning [13,14]. Despite reduced deforestation, fire frequency increased in drought years which is usually linked to anomalously warm phases of the tropical eastern Pacific (related to the El Niño Southern Oscillation, ENSO) and the northern Atlantic oceans (related to the Atlantic Multidecadal Oscillation, AMO).

Anomalously warm Sea Surface Temperature (SST) in the tropical North Atlantic weakens northeast trade wind moisture transport during the summer resulting in reduced rainfall during the dry season especially in western and southwestern Amazon [15,16]. Warm SST anomalies in the equatorial Pacific suppress convection and subsequent rainfall over the northern, central and eastern Amazon [17-19]. A combination of eastern Pacific and tropical north Atlantic warming may cause more severe, prolonged and/or widespread droughts [20-23]. In addition to extreme droughts, ongoing climate change has already influenced rainfall seasonality in the Amazon basin, by delaying the onset of the rainy 
season at the end of the calendar year which is projected to continue in the future [24]. This is not only putting the functioning of the tropical rainforest at risk but also the livelihoods of local communities living from the goods and services the Amazon rainforest provides to them [25].

In the vast Brazilian Amazonia, ground-based information on fire occurrence and impact on vegetation is scarce or anecdotal. High-resolution data are required to determine fire regimes and their respective changes caused by climate and human land-use changes [26$28]$. Remotely sensed datasets on fire occurrence (active fires) [29] and extension (burned areas) [30] enable us to fill this data gap and explore large and diverse areas such as the Brazilian Legal Amazon of more than 5 million $\mathrm{km}^{2}$ in size.

While complex network approaches have been applied to examine extreme rainfall events [31], long-term rainfall variability [32], continental moisture transport [33] and climatic factors influencing global mean temperature [34], they have not been used so far to explore fire extremes. We apply the complex networks-based methodology developed in Traxl et al. $[35,36]$ to fire data for the first time. We implement this novel methodology to identify individual fires and track their evolution over space and time. The advantages of such an individual-fires approach have been highlighted in a recent study by Andela et al. [37]. Thus, it is possible to calculate the integrated fire intensity for individual fires, and use it for the definition of extreme events. In this study, we define extreme fires as the $5 \%$ most intense fires. This subset of extreme fires is responsible for almost $30 \%$ of the total burned area in the BLA over the study period 2002-2019. We compare spatial occurrence and interannual variability of extreme fires in evergreen forests of the BLA and interpret both spatial and temporal patterns in relation to large-scale climate events, and to anthropogenic drivers such as deforestation and road development. We address the following objectives: (1) apply a novel network-based methodological approach that enables us to identify individual fires for the evaluation of spatio-temporal dynamics of extreme fires in Amazonian evergreen forests. (2) Inspect spatio-temporal differences in the distribution of extreme forest fires in years with diverse climatic conditions and degrees of anthropogenic pressure. (3) Identify potential impacts of climatic drivers such as the ENSO- and AMO-associated severe droughts, as well as anthropogenic drivers such as deforestation and distance from roads and forest edges on the spatiotemporal variability of extreme fires.

\section{Data and methods}

We define our study area following the boundaries of the Brazilian Legal Amazon (BLA), a political concept conceived to plan and promote regional development. It encompasses the states of Acre (AC), Amapá (AP), Amazonas (AM), Mato Grosso (MT), Pará (PA),
Rondônia (RO), Roraima (RR), Tocantins (TO) and part of Maranhão (MA) (ca. 5 million $\mathrm{km}^{2}$ ). Approximately, $66 \%$ of this territory was covered by tropical evergreen forests in 2018 [38] (Fig. 1), on which we focus in the present study. Apart from the Amazon biome, the BLA also includes part of the Cerrado biome, along southern MT, TO and MA, and part of the Pantanal biome in southwestern MT [39].

We retrieve the Thermal Anomalies and Fire MOD14A1 and MYD14A1 C6 datasets over the period from 2002 to 2019 to feed our spatiotemporal fire clusters algorithm. These products, which register daily hot pixels in a 1-km sinusoidal grid, are provided by the Moderate Resolution Imaging Spectroradiometer (MODIS) sensors on board the satellites Terra and Aqua [40]. Furthermore, we overlay the fire data with the annual 500-m IGBP classification scheme of the MODIS MCD12Q1 Land Cover Type C6 product in the previous year to select only those fires that occured in evergreen forests [38]. Each 1-km resolution active fire has four $500-\mathrm{m}$ resolution pixels with land-cover information. To assign a land cover to the fire clusters we aggregate the land-cover information of all the constituent events within and select the class that covers at least $80 \%$ of the cluster area. If none of the landcover classes within the cluster reach that threshold, we discard the fire. Thus, we make sure that the fires we work with are really located in a particular land-cover type. Deforestation data is supplied by the PRODES project, which monitors clear cut deforestation in the BLA since 1988 [8], and the road network is provided by the Brazilian Institute of Geography and Statistics (IBGE) $[41,42]$.

To aggregate fire data into spatiotemporal clusters that we can track over space and time, we employ network theory. In network theory, a complex system is represented as a graph. The individual parts of the system are represented by the graph's nodes, and their pairwise relations by edges. Here, we represent the MODIS fire and land-cover remote-sensing data as a graph. Pixels within the study region affected by fire constitute the nodes of the graph, while edges between them are created upon spatio-temporal proximity (Fig. 2a). We consider a pair of fire events as neighbors if they are in the same three-dimensional (latitude, longitude, time) Moore neighborhood, and no spatial or temporal gaps are allowed. The structure emerging from the constructed edges between neighboring fire events allows us to identify spatiotemporal fire clusters as the connected components of the graph (Fig. 2b). Details of the methodology used to determine the clusters computationally can be found in Traxl et al. [35].

Once the individual fires - i.e., spatiotemporal fire clusters - are identified, the integrated fire variables of their constituent fire events can be computed. Unlike in other studies where burned areas or single-pixel hotspots are employed, the individual-fires approach allows to determine which of them are extreme fires based on their integrated intensity, i.e. the Fire Radia- 


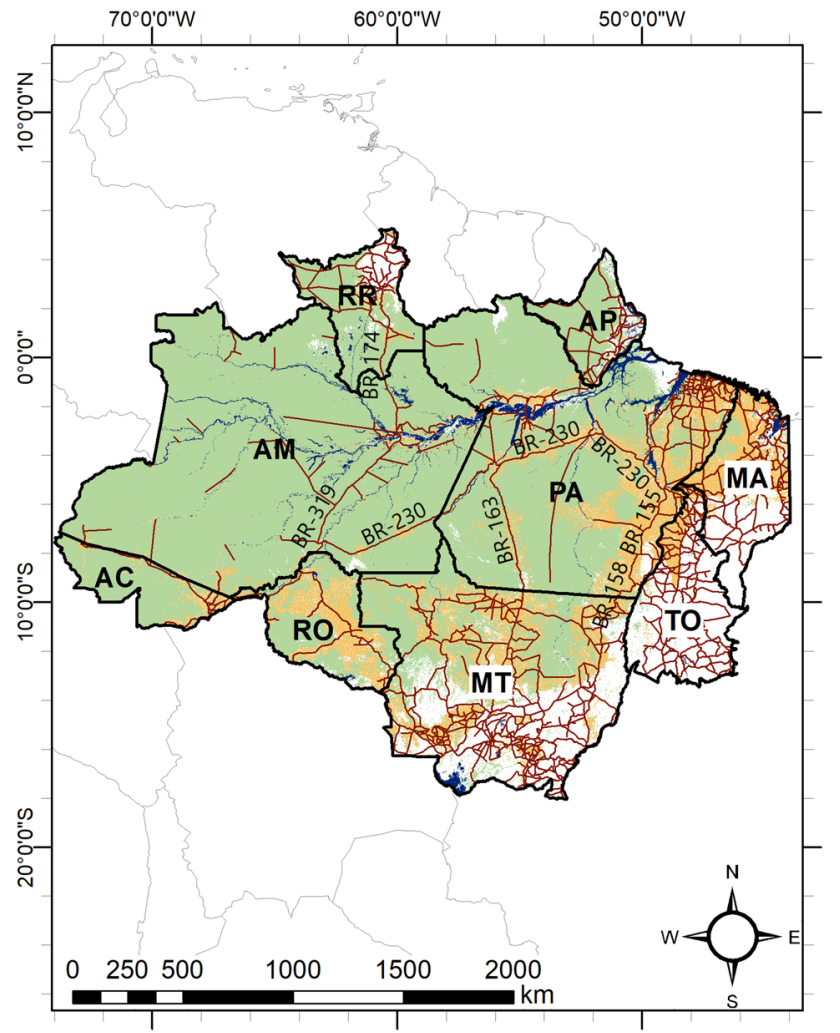

Fig. 1 Extension of tropical evergreen forests in 2018 [38] (green shaded area) and cumulative deforested area over the period 1988-2018 [8] (orange shaded area) in the different states of the Brazilian Legal Amazon: Acre (AC), Amapá (AP), Amazonas (AM), Maranhão (MA), Mato Grosso (MT), Pará (PA), Rondônia (RO), Roraima (RR) and Tocantins (TO). Main rivers are depicted in blue. Dark red solid lines indicate the geographical location of main roads [42]. Primary roads in the tropical forest are labelled. The Trans-Amazonian highway (BR-230), the most extensive project ever planned in the Amazon tropical forest, runs along $4000 \mathrm{~km}$ from the state of Paraíba in the northeast region of Brazil to the state of AM. The BR-163 links Cuiabá, in central Brazil, and Santarém (PA), on the southern margin of the Amazon river, connecting crop production centers in MT with the international port of Santarém. The BR-158 and BR-155 were planned to connect agricultural poles in northeastern MT and the port of Marabá (PA). The BR-319 runs through a pristine area of the Amazon tropical forest from Manaus (AM) to Porto Velho (RO) as an alternative to the waterway to transport products from the Manaus Free Trade Zone to São Paulo. The BR-174 connects Manaus (AM) with the state of $\mathrm{RR}$ and continues to Venezuela, being the only road connection of the state of $\mathrm{RR}$ with the rest of the country

tive Power (FRP). We chose to analyse fire intensity (i.e. the radiant energy released by fires), because it is a crucial variable to estimate socio-ecological impacts of fires as well as burned biomass and fire-induced emissions $[43,44]$. We select only extreme forest fires, meaning those fires whose intensity (FRP) was greater than or equal to the 95th percentile of the variables' distri- bution, i.e. the most intense $5 \%$ of the sample. Extreme fires largely contribute to the total forest burned, since $70 \%$ of the extreme fires are also within the $5 \%$ largest fires (by area) identified. In the context of the entire study period, extreme fires accounted for almost $70 \%$ of the total integrated intensity, and almost $30 \%$ of the total integrated burned area in the BLA forests (data not shown). Henceforth, we will refer to the extreme individual fires in Amazonian tropical forests simply as extreme fires.

\section{Results and discussion}

\subsection{Temporal variability}

We find a total of 351.991 fire clusters in tropical evergreen forests of the BLA over the period 2002-2019, which account for $43 \%$ of the total number of fire clusters registered in the 18-year period in the region. Of those, a total of 17.606 fire clusters were categorised as extreme events - the most intense 5\% - and selected from the sample. We observe that the interannual variability of extreme forest fires shows a strong, positive relationship with drought and/or high deforestation years (Fig. 3a). When plotting the annual number of extreme fires against the total number of fires, we find a strong linear correlation with a Pearson correlation coefficient of 0.97 . The highest ratios are observed at the beginning of the study period (2003-2006) when deforestation rates were the highest (Fig. 3b).

The most severe droughts registered in Amazonia in the twenty-first century were linked to ENSO and/or AMO events. As several studies have reported, those events are associated with increased mean temperature, decreased levels of rainfall, and an extended dry season $[17,46,47]$. The year 2005 witnessed an extensive AMO-associated drought identified as a 1-in-100year event in the BLA [16,48]. The 2010 drought started during an El Niño event and then became more intense with the anomalous warming of the tropical north Atlantic [16,21]. The combination of both phenomena caused the 2010 drought to be more severe and remain for longer than the 2005 drought [49]. Lewis et al. [16] found that ca. $60 \%$ more area was affected by the drought in 2010 compared to the year 2005. At the end of the year 2015 and beginning of 2016, one of the greatest El Niño events of the last decades - combined with the regional warming trendstruck the region with unprecedented warming and the most extensive area under extreme drought severity $[19,50]$.

Of the total deforestation in the BLA over the study period, $45 \%$ occurred in the first four years (20022005) [8], peaking in 2004 (Fig. 3a). At that time, as Aragão et al. [51] stated, land conversion through deforestation was one of the main drivers of fire dynamics in the region. Through successful public policy (PPCDAm) and later interventions in beef and soy supply chains $[52,53]$, a declining deforestation trend was 


\section{a}

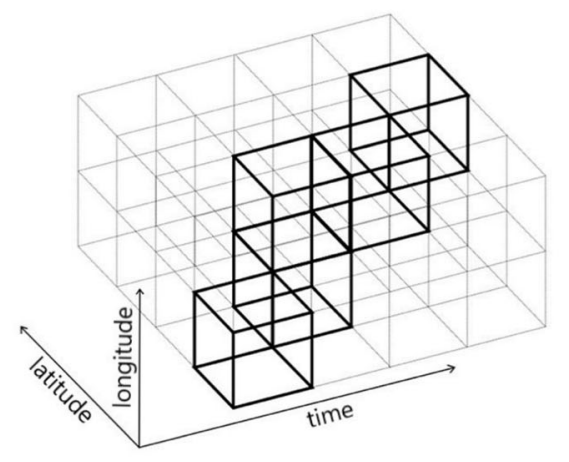

b

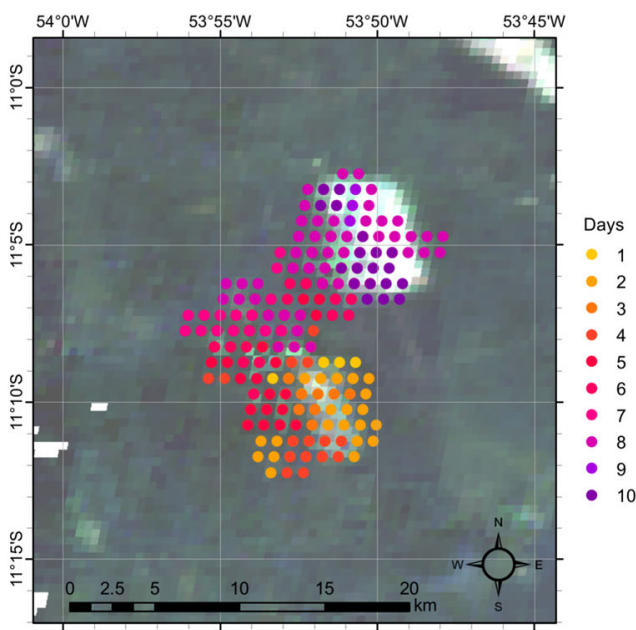

and time of an extreme fire registered in northeastern Mato Grosso in 2004. It lasted 10 days, starting on the 04.09.2004. Each dot represents an active fire within the extreme fire cluster, and the different colours indicate each of the time steps of the extreme fire cluster development. Background is the MODIS Nadir BRDF-Adjusted Reflectance (NBAR) 500-m resolution daily product (MCD43A4) [45] on the day when the fire started

and widespread drought severity in the years 20152016. Jiménez-Muñoz et al. [49] found that up to $13 \%$ of Amazonian tropical forests endured extreme drought at the beginning of 2016, which set the conditions for more extreme forest fires in 2017. On the other hand, the year 2013 was classified as exceptionally wet based on the positive rainfall anomalies and a short dry season [11]. These conditions did not promote high intensity forest fires and therefore, we observed the lowest number of extreme fires (179 events, Fig. 3a) over the study period in that year.

In the year 2019, in the absence of particular drought conditions, we find an increase of $57 \%$ in extreme fires compared to the previous year, and the highest number since 2007 (Fig. 3a). The density of extreme fires over the BLA in $2019\left(2.6 \times 10^{-4}\right.$ extreme fires $/ \mathrm{km}^{2}$ tropical forest) was even greater than in years when severe droughts struck the region, e.g. in 2010 and 2015 (Fig. 3a). In Amazonia, Barlow et al. [55] observed three times as many active fires in August 2019 - typically the peak of the fire season (alongside September) - than in the same month in 2018. Also, Lizundia-Loiola et al. [58] found a larger amount of burned area in Brazil in 2019 than in the previous year. Both studies align with our findings of increased extreme fire activity in the tropical forests of the BLA in 2019 compared to the previous year. When we consider the most recent years, i.e. the time interval from 2007 to 2019, we find an above-average number of extreme fires in 2019. However, if set into the context of the entire study period (2002-2019), we observe that 2019 is below average. When taking this 18-year period into account, the high- 
Fig. 3 a Annual amount of fires (gray bars, right $y$-axis) and extreme fires (black bars, left $y$-axis) in tropical forests of the Brazilian Legal Amazon over the period 2002-2019. The gray line (right $y$-axis) displays the annual deforested area. Labels A and $\mathrm{E}$ indicate the anomalous warming of the northern Atlantic (AMO) and tropical eastern Pacific (ENSO) oceans, respectively, which are related with reduced rainfall. Stars denote the selected years for the analysis. b Relationship between annual extreme fires and total fires. Triangles denote high deforestation years (above average for the period 2002-2019). Symbols of years selected for the analysis are shown in red

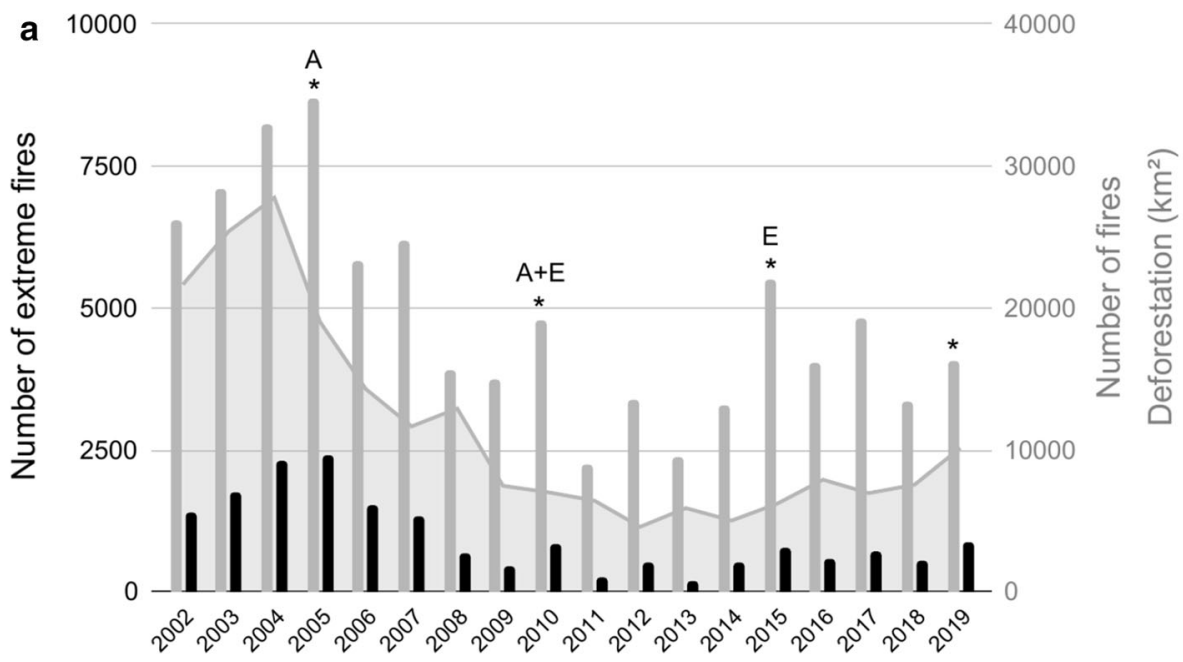

fires $\square$ extreme fires

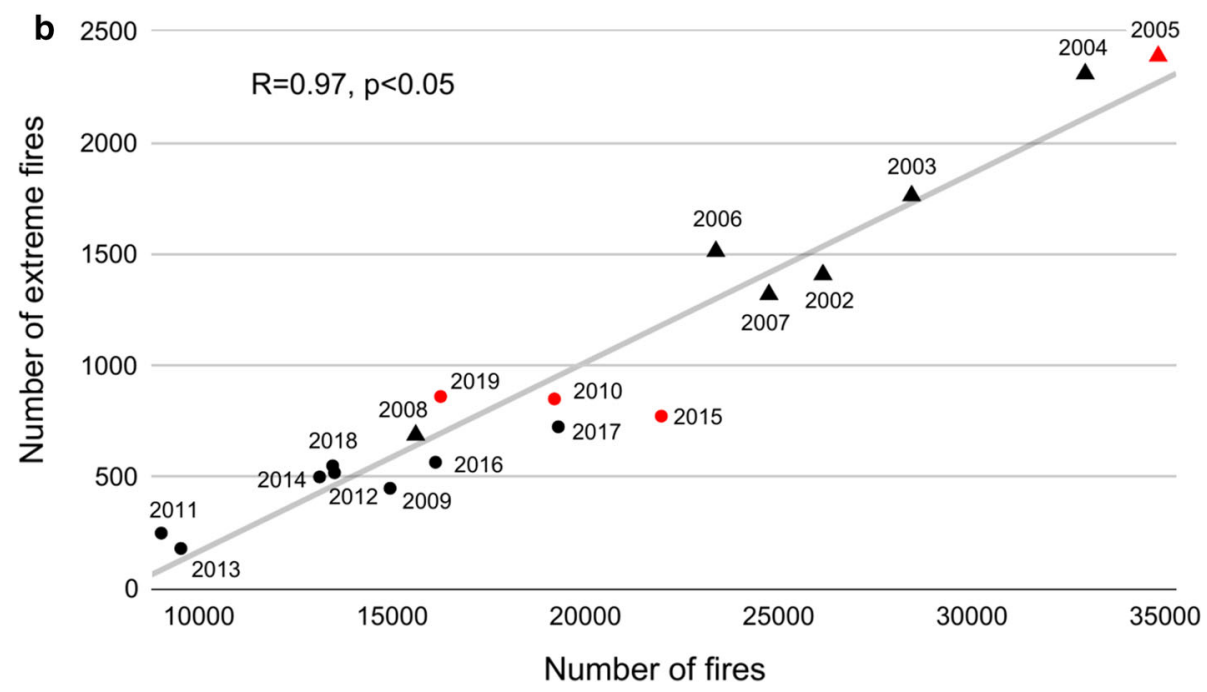

est extreme fire years are concentrated at the beginning of the time-series (Fig. 3a), or at the upper end when plotting numbers of extreme fires against numbers of fires (Fig. 3b). Lizundia-Loiola et al. [58] also reported the 2019 annual area burned in Brazil being close to the long-term average. The increase in extreme fire activity which we also found in 2019 (Fig. 3a) has been associated with increasing deforestation rates by several studies [59-61]. In agreement with that, we find $34 \%$ more deforested area in 2019 than in the previous year, and the highest deforestation rate since 2009 (Fig. 3a). Clear-cut deforestation for agriculture and rangelands raises emissions of aerosols and greenhouse gases from fires used in the process [62]. In 2019, thick, dark smoke from the Amazon deforestation fires reached distant big cities, including São Paulo [63], which received a lot of political attention and media coverage. Public awareness of the critical situation of the Amazon forests and the negative impact of these fires on public health increased during this episode [64].

\subsection{Spatial variability}

Our study reveals differences in the spatial distribution of extreme forest fires as well as certain patterns that remain stable over the study period. Droughts co-occur with a high number of extreme fires in the years 2005, 2010 and 2015 (Fig. 3a), although there is some variability in the spatial distribution. We find a large number of extreme fires concentrated in the states of Acre, Rondônia, northern half of Mato Grosso and Pará in 2005 (Fig. 4a). This is consistent with previous studies that locate the epicentre of the AMO-driven drought of 2005 in western Amazonia $[65,66]$. In 2010, both the El Niño and warming of the tropical north Atlantic occurred simultaneously and areas in the southwestern Amazonia and the state of MT were especially affected, as reported by previous research $[16,47]$, and as shown in Fig. 4b. In 2015, extreme fires concentrated in northeastern Amazonia (Fig. 4c) as a result of the impact of one of the strongest ENSO events on record [67,68]. By estimating the relative percentage difference between the extreme fires distribution per states in 2015 and 

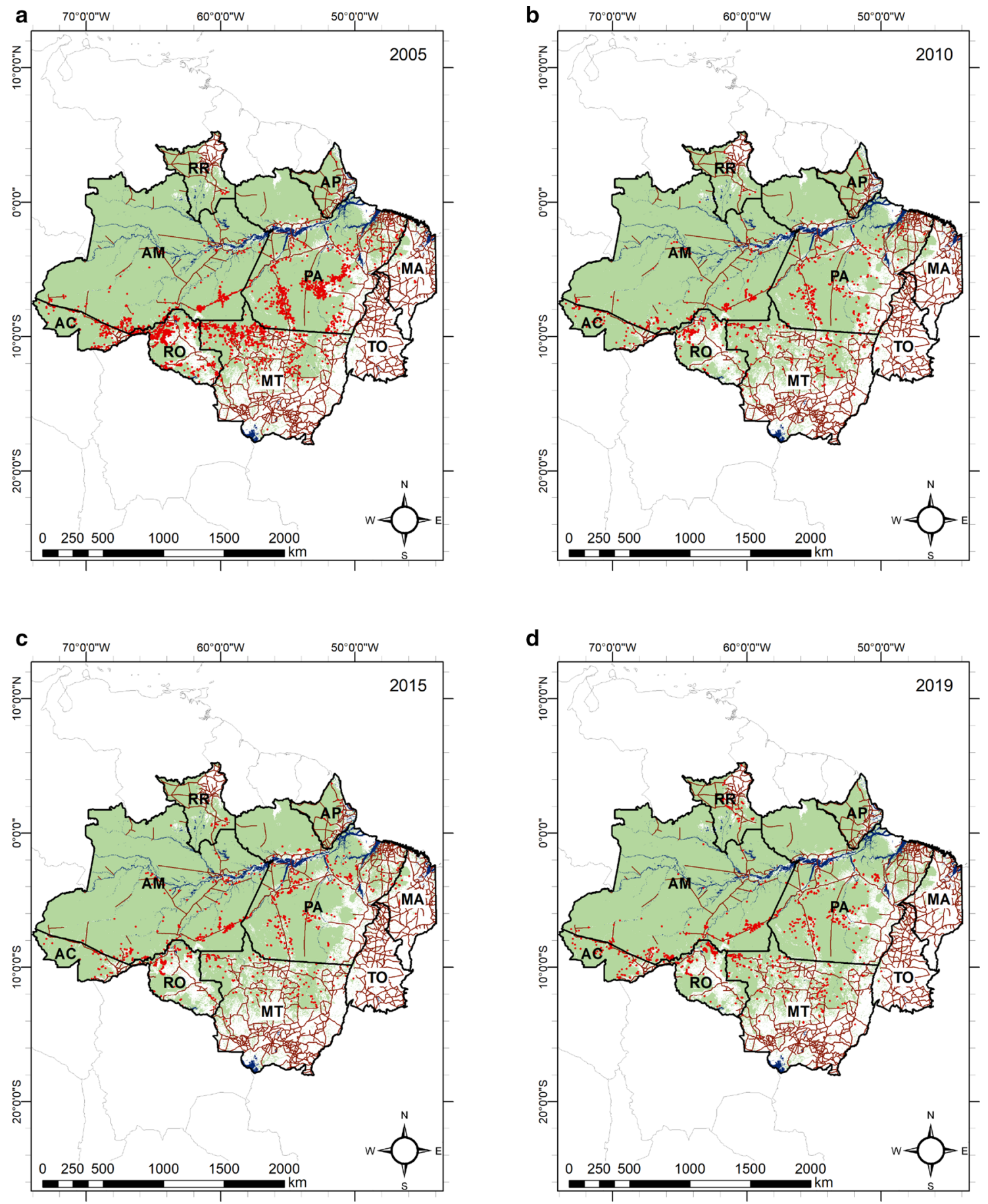

Fig. 4 Spatial distribution of extreme forest fires in the Brazilian Legal Amazon in a 2005, b 2010, c 2015, and d 2019. Fire clusters are represented by red points. Dark red solid lines indicate the geographical location of main roads

2005, the spatial shift becomes apparent. In 2015, the number of extreme fires increased only in the states of Roraima and Maranhão (157\% and 47\% of increase, respectively) compared to values in 2005 . The most significant decrease in the number of extreme forest fires in 2015 was observed in Mato Grosso (83\%), Rondônia

[42]. The extension of the tropical evergreen forest [38] is demarcated in green. See Fig. 1 for names and details of the roads

(81\%) and Acre (78\%). This means, more extreme fires occurred in the southwestern states (MT, RO and AC) in 2005, but concentrated in the northern and eastern states (RR, MA) in 2015.

The fact that the drought in 2015 was more intense and extensive but registered lower fire activity than 
during the 2005 drought (Fig. 4a vs. c) points to deforestation as the dominant driver of extreme fires. It is known that forest fragmentation and edge effects from deforestation expose forests to warm conditions allowing fuel loads to dry out more rapidly and therefore, sustain higher-intensity fires $[69,70]$. Thus, the high deforestation rate registered in 2005 (Fig. 3a) is linked to the high number of extreme fires in that year. We discover that every single extreme fire we identified in the tropical forests over the entire study period is within 0.5$\mathrm{km}$ reaching distance from forest edges, i.e. deforested areas, activities related to mining and logging, as well as clearings for small ranching and farming, both legal and illegal. The states of Amazonas and Pará accounted for $73 \%$ of the evergreen forests in the BLA in 2018. However, while PA concentrated $32 \%$ of the total deforestation in the BLA over the period 2002-2019, AM accumulated only $8 \%$ of the total deforestation [8]. Tropical forests in PA have been more heavily impacted than in AM, mainly due to the higher number of roads developed in PA (Figs. 1, 4). There is a consensus that roads are directly and indirectly related to deforestation [7173]. The transportation network increases forest accessibility and rapid expansion of the agricultural frontier into the forests, which perpetuates forest degradation [74-76]. The typical pattern of forest colonisation leads to the opening of secondary paths branching from main roads, which allow new settlers to penetrate further into the tropical forests. We observe a clear arrangement of extreme fires along roads, for instance following the Trans-Amazonian highway (BR-230), the largest infrastructure project through the tropical forest in the BLA (Figs. 1, 4). Another example is the characteristic fire pattern in PA along a polygon formed by the highways BR-163, BR-230, BR-155 and BR-158, which connect agricultural and timber production centers with distribution ports (Figs. 1, 4).

We explore the spatial distribution of extreme fires with respect to the road network in 2005 [41] and 2014 [42] and find a strong correlation between them. We notice that $57 \%$ and $40 \%$ of the total number of extreme fires are within 1-km distance from roads in 2005 and 2014 , respectively. If the distance is expanded to a radius of $5 \mathrm{~km}$ from roads, we find $75 \%$ in 2005 and $61 \%$ in 2014 of the extreme fires within that area (Fig. 5). We deduce that the higher number of extreme fires close to roads in 2005 compared to 2014 is related to the high deforestation activity reported in 2005 (Fig. 3a) and the need of a very large number of paths in the tropical forests to reach the deforestation sites. By the year 2014, following a significant drop in deforestation rates (Fig. 3a), road opening activities had decreased very much, and also an important number of the paths constructed in 2005 had been abandoned. Thus, the lower number of roads in use in 2014 led to a reduced number of extreme fires linked to roads. It is very important to consider that new unofficial or illegal unpaved roads are constantly being opened in the tropical forests [77], which makes it difficult to keep road maps in the region up to date. This suggests that even higher numbers of

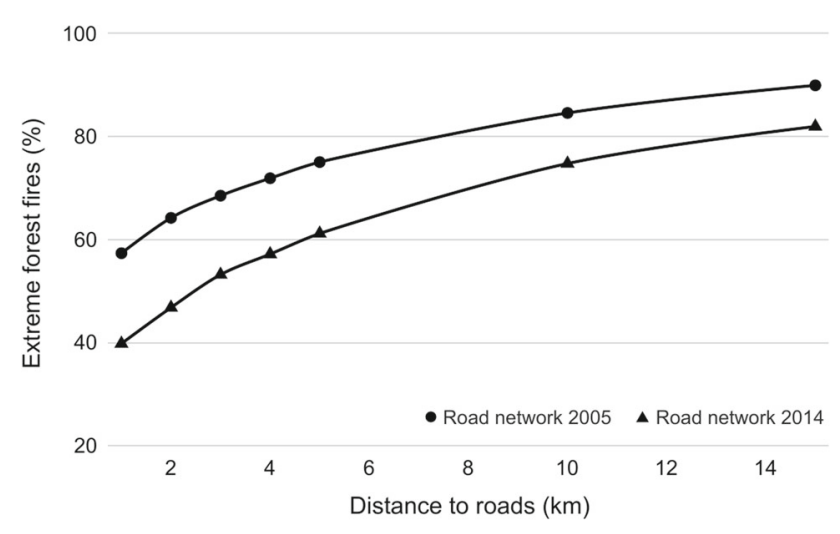

Fig. 5 Cumulative number of extreme fires in the Brazilian Legal Amazon (in percentage) within various distances from the road network in 2005 (points) [41] and 2014 (triangles) [42]. Input data is subject to uncertainty due to the lack of resources to register unofficial or illegal unpaved roads. Even higher numbers of extreme fires may be connected to roads in Amazonian forests than quantified here

extreme fires may be connected to roads in Amazonian forests than quantified in our analysis.

The dominance of anthropogenic drivers on the spatial distribution of extreme forest fires is also observed in 2019, when significant fire activity was registered despite average climatic conditions. In that year, the highest deforestation rate in the BLA since 2009 helps to explain the high fire activity (Fig. 3a). The spatiotemporal link between deforestation and fire that was observed in the early 2000s has been reported again in the last years [59]. We detected some unusual fire activity in the states of Roraima and the southern and central regions of Amazonas in 2019 (Fig. 4d), compared to the spatial patterns of extreme fires in the other years analysed. Thus, extreme fire distribution in $\mathrm{RR}$ and AM is likely to be related to ignition sources provided by increasing deforestation activities for agricultural expansion, the main driver of fire activity in the region in 2019 [58]. Agriculture frontier expansion increases the risk of escaping fires from managed agropastoral lands [13]. The current Brazilian government, strongly supported by the powerful agribusiness sector, operates to open the vast and ecologically sensitive Amazon rainforests to greater commercial exploitation $[78,79]$, which poses an additional threat to tropical forest conservation.

While global climate change has the potential to increase drought conditions, anthropogenic drivers of forest degradation (deforestation, roads, logging, mining, farming, etc.) provide the ignition sources that determine fire distribution in the sensitive tropical forests of the BLA $[68,80]$. Furthermore, anthropogenic fire behaviour adapts to the eco-climatic conditions $[81,82]$. Even localised drought conditions may encourage anomalous increased anthropogenic fire activity through deforestation and land management [83]. In line with this, we observe spatiotemporal correspondence between high extreme fire years and drought 
years and/or high deforestation years. According to our findings, all the extreme fires are a direct consequence of forest clearing, and therefore, they are always associated with forest edges. Among the activities responsible for creating forest edges, we find that roads are a prominent factor in defining the spatial distribution of extreme fires. Comparing the spatial patterns of extreme fires in years with different regional climatic conditions and degrees of human influence helps us to identify the most affected areas in each case (Fig. 4). The individual-fires approach also allows us to flag locations that burn for the first time, e.g. are part of the pristine tropical evergreen forests or previously protected areas, and to disentangle the diverse and interrelated fire driving forces. Focus should be put on identifying the agents who cause fires, and applying specific measures to halt the fire-driven transformation of tropical Amazonian forests and, therefore, reduce its associated carbon emissions.

\section{Conclusions}

In this study, we use a novel network-based representation of fire events in order to track and investigate local formations of spatio-temporal fire clusters of high intensity in evergreen forests of the BLA. Our findings are in line with previous studies underscoring that both climatic and anthropogenic factors determine the spatiotemporal distribution of extreme fires in the region. We observe that climatic extreme events define the interannual fluctuation of extreme fires but they also affect their spatial distribution. The epicenter/s of droughts induced by ENSO- and AMO-events or a combination of both, are usually spatially distinct in Amazonian tropical forests. The interannual variability and spatial distribution of deforestation also helps to explain extreme fire patterns in Amazonian tropical forests. The link between fire activity and deforestation was strong until the year 2005, after which policies implemented to prevent deforestation led to some spatiotemporal decoupling between both processes. However, in recent years, and especially in 2019, data suggest that the connection between fire activity and deforestation is getting stronger again. Spatially, all identified extreme fires were located within $0.5-\mathrm{km}$ distance from forest edges, which are constantly growing as a consequence of forest-clearing for a wide range of purposes. Extreme fires are closely distributed along the roads that run through the Amazon tropical forests. Apart from augmenting forest flammability at the drier forest edges, roads allow further colonisation of the Amazon pristine forest bringing ignition sources into the forests through activities such as logging, grazing and farming. We find up to $57 \%$ of extreme fires within 1-km distance from roads and up to $75 \%$ if the distance is extended to $5 \mathrm{~km}$. Our results highlight the relevance of properly assessing the synergistic effects of continued deforestation, ongoing climate change and fire to control the advancement of forest degradation. This knowledge should feed into the strategies and policy mechanisms aimed to protect the undisturbed Amazonian forests.

Acknowledgements A.C.C. acknowledges the financial support from the IRTG 1740/TRP 2011/50151-0 funded by the DFG/FAPESP, and the BMBF- and Belmont Forum-funded project "CLIMAX: Climate services through knowledge co-production: A Euro-South American initiative for strengthening societal adaptation response to extreme events", FKZ 01LP1610A. D.T. was also supported by the IRTG 1740/TRP and the State of Brandenburg (Germany) through the Ministry of Science and Education (grant to Bodo Bookhagen). Authors want to thank the Potsdam Institute for Climate Impact Research for its high-performance computing facility. MODIS Active Fires (MOD/MYD14A1) and Land Cover Type (MCD12Q1) data are available at the NASA's Atmosphere Archive and Distribution System (LAADS) Distributed Active Archive Center (DAAC) at http://ladsweb.modaps.eosdis.nasa.gov. Annual deforestation data (PRODES Project) are available at http://terrabrasilis.dpi.inpe.br/downloads. Road network from the Brazilian Institute of Geography and Statistics (IBGE) is available at https://www.ibge.gov.br/en/ geosciences/downloads-geosciences.html. The processed fire clusters dataset used in this study is available online: https://zenodo.org/record/4461575.

Funding Open Access funding enabled and organized by Projekt DEAL.

\section{Author contribution statement}

A.C.C.: Conceptualisation, Methodology, Formal analysis, Writing original draft, Visualisation; D.T.: Methodology, Software, Writing review and editing, K.T.: Writing review and editing, Supervision.

Open Access This article is licensed under a Creative Commons Attribution 4.0 International License, which permits use, sharing, adaptation, distribution and reproduction in any medium or format, as long as you give appropriate credit to the original author(s) and the source, provide a link to the Creative Commons licence, and indicate if changes were made. The images or other third party material in this article are included in the article's Creative Commons licence, unless indicated otherwise in a credit line to the material. If material is not included in the article's Creative Commons licence and your intended use is not permitted by statutory regulation or exceeds the permitted use, you will need to obtain permission directly from the copyright holder. To view a copy of this licence, visit http://creativecomm ons.org/licenses/by/4.0/.

\section{References}

1. J.R. Marlon, P.J. Bartlein, C. Carcaillet, D.G. Gavin, S.P. Harrison, P.E. Higuera, F. Joos, M.J. Power, I.C. Prentice, Climate and human influences on global biomass burning over the past two millennia. Nature 
Geosci. 1(10), 697-702 (2008). https://doi.org/10.1038/ ngeo313

2. D.M.J.S. Bowman, J. Balch, P. Artaxo, W.J. Bond, M.A. Cochrane, C.M. D'Antonio, R. DeFries, F.H. Johnston, J.E. Keeley, M.A. Krawchuk, C.A. Kull, M. Mack, M.A. Moritz, S. Pyne, C.I. Roos, A.C. Scott, N.S. Sodhi, T.W. Swetnam, The human dimension of fire regimes on Earth. J. Biogeogr. 38(12), 22232236 (2011). https://doi.org/10.1111/j.1365-2699.2011. 02595.x

3. S.L. Lewis, D.P. Edwards, D. Galbraith, Increasing human dominance of tropical forests. Science 349(6250), 827-832 (2015). https://doi.org/10.1126/ science.aaa9932

4. J. Mistry, A. Berardi, V. Andrade, T. Krahô, P. Krahô, O. Leonardos, Indigenous fire management in the cerrado of Brazil: the case of the Krahô of Tocantíns. Hum. Ecol. 33(3), 365-386 (2005). https://doi.org/10.1007/ s10745-005-4143-8

5. V.R. Pivello, The use of fire in the Cerrado and Amazonian rainforests of Brazil: past and present. Fire Ecol. 7(1), 24-39 (2011). https://doi.org/10.4996/fireecology. 0701024

6. M.A. Cochrane, M.D. Schulze, Fire as a recurrent event in tropical forests of the eastern Amazon: effects on forest structure, biomass, and species composition. Biotropica 31(1), 2-16 (1999). https://doi.org/10.2307/ 2663955

7. P.M. Brando, J.K. Balch, D.C. Nepstad, D.C. Morton, F.E. Putz, M.T. Coe, D. Silverio, M.N. Macedo, E.A. Davidson, C.C. Nobrega, A. Alencar, B.S. SoaresFilho, Abrupt increases in Amazonian tree mortality due to drought-fire interactions. Proc. Natl. Acad. Sci. USA 111(17), 6347-6352 (2014). https://doi.org/10. 1073 /pnas. 1305499111

8. INPE, Instituto Nacional de Pesquisas Espaciais, Coordenação Geral de Observação da Terra. Programa de monitoramento da Amazônia e demais biomas, Desmatamento na Amazônia Legal (Projeto PRODES) (2020). http://terrabrasilis.dpi.inpe.br/downloads

9. D. Nepstad, D. McGrath, C. Stickler, A. Alencar, A. Azevedo, B. Swette, T. Bezerra, M. DiGiano, J. Shimada, R. Seroa da Motta, E. Armijo, L. Castello, P. Brando, M.C. Hansen, M. McGrath-Horn, O. Carvalho, L. Hess, Slowing Amazon deforestation through public policy and interventions in beef and soy supply chains. Science 344(6188), 1118-1123 (2014). https://doi.org/ 10.1126 /science. 1248525

10. H.K. Gibbs, L. Rausch, J. Munger, I. Schelly, D.C. Morton, P. Noojipady, B. Soares-Filho, P. Barreto, L. Micol, N.F. Walker, Brazil's Soy Moratorium. Science 347(6220), 377-378 (2015). https://doi.org/10.1126/ science.aaa0181

11. L.E.O.C. Aragão, L.O. Anderson, M.G. Fonseca, T.M. Rosan, L.B. Vedovato, F.H. Wagner, C.V.J. Silva, C.H.L. Silva Junior, E. Arai, A.P. Aguiar, J. Barlow, E. Berenguer, M.N. Deeter, L.G. Domingues, L. Gatti, M. Gloor, Y. Malhi, J.A. Marengo, J.B. Miller, O.L. Phillips, S. Saatchi, 21st Century drought-related fires counteract the decline of Amazon deforestation carbon emissions. Nat. Commun. 9(1), 536 (2018). https://doi. org/10.1038/s41467-017-02771-y
12. R. Libonati, J.M.C. Pereira, C.C. Da Camara, L.F. Peres, D. Oom, J.A. Rodrigues, F.L.M. Santos, R.M. Trigo, C.M.P. Gouveia, F. Machado-Silva, A. EnrichPrast, J.M.N. Silva, Twenty-first century droughts have not increasingly exacerbated fire season severity in the Brazilian Amazon. Sci. Rep. 11(1), 4400 (2021). https://doi.org/10.1038/s41598-021-82158-8

13. A. Cano-Crespo, P.J.C. Oliveira, A. Boit, M. Cardoso, K. Thonicke, Forest edge burning in the Brazilian Amazon promoted by escaping fires from managed pastures. J. Geophys. Res. Biogeosci. 120(10), 2095-2107 (2015). https://doi.org/10.1002/2015JG002914

14. C.H.L. Silva Junior, L.E.O.C. Aragão, M.G. Fonseca, C.T. Almeida, L.B. Vedovato, L.O. Anderson, Deforestation-induced fragmentation increases forest fire occurrence in Central Brazilian Amazonia. Forests 9(6), 305 (2018). https://doi.org/10.3390/f9060305

15. N. Zeng, J.H. Yoon, J.A. Marengo, A. Subramaniam, C.A. Nobre, A. Mariotti, J.D. Neelin, Causes and impacts of the 2005 Amazon drought. Environ. Res. Lett. 3(1), 014002 (2008). https://doi.org/10.1088/ $1748-9326 / 3 / 1 / 014002$

16. S.L. Lewis, P.M. Brando, O.L. Phillips, G.M.F. van der Heijden, D. Nepstad, The 2010 Amazon drought. Science 331(6017), 554 (2011). https://doi.org/10.1126/ science. 1200807

17. J.S. Panisset, R. Libonati, C.M.P. Gouveia, F. Machado-Silva, D.A. França, J.R.A. França, L.F. Peres, Contrasting patterns of the extreme drought episodes of 2005, 2010 and 2015 in the Amazon Basin. Int. J. Climatol. 38(2), 1096-1104 (2018). https://doi.org/10. $1002 /$ joc. 5224

18. J.C. Jimenez, J. Barichivich, C. Mattar, K. Takahashi, A. Santamaría-Artigas, J.A. Sobrino, Y. Malhi, R. Libonati, L.F. Peres, Spatio-temporal patterns of thermal anomalies and drought over tropical forests driven by recent extreme climatic anomalies. Philos. Trans. R. Soc. B 373, 20170300 (2018). https://doi.org/10.1098/ rstb. 2017.0300

19. C.H.L. Silva Junior, L.O. Anderson, A.L. Silva, C.T. Almeida, R. Dalagnol, M.A.J.S. Pletsch, T.V. Penha, R.A. Paloschi, L.E.O.C. Aragão, Fire responses to the 2010 and 2015/2016 Amazonian droughts. Front. Earth Sci. 7, 97 (2019). https://doi.org/10.3389/feart.2019. 00097

20. J.H. Yoon, N. Zeng, An Atlantic influence on Amazon rainfall. Clim. Dyn. 34(2), 249-264 (2010). https://doi. org/10.1007/s00382-009-0551-6

21. J.A. Marengo, J. Tomasella, L.M. Alves, W.R. Soares, D.A. Rodriguez, The drought of 2010 in the context of historical droughts in the Amazon region. Geophys. Res. Lett. 38(12), L12703 (2011). https://doi.org/10.1029/ 2011GL047436

22. C.A.S. Coelho, I.A.F. Cavalcanti, S.M.S. Costa, S.R. Freitas, E.R. Ito, G. Luz, A.F. Santos, C.A. Nobre, J.A. Marengo, A.B. Pezza, Climate diagnostics of three major drought events in the Amazon and illustrations of their seasonal precipitation predictions. Meteorol. Appl. 19(2), 237-255 (2012). https://doi.org/10.1002/ met.1324

23. Y. Zou, E.E.N. Macau, G. Sampaio, A.M.T. Ramos, J. Kurths, Do the recent severe droughts in the Amazonia have the same period of length? Clim. 
Dyn. 46(9), 3279-3285 (2016). https://doi.org/10.1007/ s00382-015-2768-x

24. J.A. Marengo, C.M. Souza, K. Thonicke, C. Burton, K. Halladay, R.A. Betts, L.M. Alves, W.R. Soares, Changes in climate and land use over the Amazon region: current and future variability and trends. Front. Earth Sci. 6, 228 (2018). https://doi.org/10.3389/feart.2018.00228

25. C.A. Nobre, G. Sampaio, L.S. Borma, J.C. CastillaRubio, J.S. Silva, M. Cardoso, Land-use and climate change risks in the Amazon and the need of a novel sustainable development paradigm. Proc. Natl. Acad. Sci. USA 113(39), 10759-10768 (2016). https://doi.org/10. 1073/pnas.1605516113

26. R.A. Silvestrini, B.S. Soares-Filho, D. Nepstad, M. Coe, H. Rodrigues, R. Assunção, Simulating fire regimes in the Amazon in response to climate change and deforestation. Ecol. Appl. 21(5), 1573-1590 (2011). https:// doi.org/10.1890/10-0827.1

27. V.H. Gutiérrez-Vélez, M. Uriarte, R. DeFries, M. Pinedo-Vásquez, K. Fernandes, P. Ceccato, W. Baethgen, C. Padoch, Land cover change interacts with drought severity to change fire regimes in Western Amazonia. Ecol. Appl. 24(6), 1323-1340 (2014). https://doi. org/10.1890/13-2101.1

28. D.P. Roy, S.S. Kumar, Multi-year MODIS active fire type classification over the Brazilian Tropical Moist Forest Biome. Int. J. Digit. Earth 10(1), 54-84 (2016). https://doi.org/10.1080/17538947.2016.1208686

29. L. Giglio, W. Schroeder, C.O. Justice, The collection 6 MODIS active fire detection algorithm and fire products. Remote Sens. Environ. 178, 31-41 (2016). https:// doi.org/10.1016/j.rse.2016.02.054

30. L. Giglio, L. Boschetti, D.P. Roy, M.L. Humber, C.O. Justice, The collection 6 MODIS burned area mapping algorithm and product. Remote Sens. Environ. 217, 7285 (2018). https://doi.org/10.1016/j.rse.2018.08.005

31. N. Boers, B. Bookhagen, H.M.J. Barbosa, N. Marwan, J. Kurths, J.A. Marengo, Prediction of extreme floods in the eastern Central Andes based on a complex networks approach. Nat. Commun. 5(1), 5199 (2014). https://doi. org $/ 10.1038 /$ ncomms6199

32. C. Ciemer, N. Boers, M. Hirota, J. Kurths, F. MüllerHansen, R.S. Oliveira, R. Winkelmann, Higher resilience to climatic disturbances in tropical vegetation exposed to more variable rainfall. Nat. Geosci. 12(3), 174-179 (2019). https://doi.org/10.1038/s41561-019-0312-z

33. D.C. Zemp, C.-F. Schleussner, H.M.J. Barbosa, R.J. van der Ent, J.F. Donges, J. Heinke, G. Sampaio, A. Rammig, On the importance of cascading moisture recycling in South America. Atmos. Chem. Phys. 14(23), 13337-13359 (2014). https://doi.org/10.5194/ acp-14-13337-2014

34. B. Goswami, N. Marwan, G. Feulner, J. Kurths, How do global temperature drivers influence each other? Eur. Phys. J. Spec. Top. 222(3), 861-873 (2013). https://doi. org/10.1140/epjst/e2013-01889-8

35. D. Traxl, N. Boers, J. Kurths, Deep graphs - a general framework to represent and analyze heterogeneous complex systems across scales. Chaos 26(6), 065303 (2016). https://doi.org/10.1063/1.4952963

36. D. Traxl, N. Boers, A. Rheinwalt, B. Goswami, J. Kurths, The size distribution of spatiotemporal extreme rainfall clusters around the globe. Geophys. Res.
Lett. 43, 9939-9947 (2016). https://doi.org/10.1002/ 2016GL070692

37. N. Andela, D.C. Morton, L. Giglio, R. Paugam, Y. Chen, S. Hantson, G.R. van der Werf, J.T. Randerson, The Global Fire Atlas of individual fire size, duration, speed and direction. Earth Syst. Sci. Data 11(2), 529552 (2019). https://doi.org/10.5194/essd-11-529-2019

38. M. Friedl, D. Sulla-Menashe, MCD12Q1 MODIS Terra/Aqua Land Cover Type Yearly L3 Global 500m SIN Grid V006, The Land Processes Distributed Active Archive Center (LP DAAC), NASA (2019). https:// lpdaac.usgs.gov/products/mcd12q1v006

39. IBGE, Instituto Brasileiro de Geografia e Estatística, Coordenação de Recursos Naturais e Estudos Ambientais. Biomas e sistema costeiro-marinho do Brasil (2019). https://biblioteca.ibge.gov.br/visualizacao/ livros/liv101676.pdf

40. L. Giglio, C. Justice, MOD14A1/MYD14A1 MODIS Terra/Aqua Thermal Anomalies/Fire Daily L3 Global $1 \mathrm{~km}$ SIN Grid V006, The Land Processes Distributed Active Archive Center (LP DAAC), NASA (2015). https://lpdaac.usgs.gov/products/mod14a1v006/ and https://lpdaac.usgs.gov/products/myd14a1v006/

41. IBGE, Instituto Brasileiro de Geografia e Estatística, mapa de Infraestructura de Transportes (2005). https://www.ibge.gov.br/geociencias/ organizacao-do-territorio/redes-e-fluxos-geograficos/ 15793-logistica-dos-transportes.html?=\&t=downloads

42. IBGE, Instituto Brasileiro de Geografia e Estatística, Mapa de Logistica dos Transportes no Brasil (2014). https://www.ibge.gov.br/geociencias/ organizacao-do-territorio/redes-e-fluxos-geograficos/ 15793-logistica-dos-transportes.html?=\&t=downloads

43. P.J. Crutzen, M.O. Andreae, Biomass burning in the tropics: impact on atmospheric chemistry and biogeochemical cycles. Science 250(4988), 1669-1678 (1990). https://doi.org/10.1126/science.250.4988.1669

44. M.J. Wooster, G. Roberts, G.L.W. Perry, Y.J. Kaufman, Retrieval of biomass combustion rates and totals from fire radiative power observations: FRP derivation and calibration relationships between biomass consumption and fire radiative energy release. J. Geophys. Res. Atmos. 110, D24311 (2005). https://doi.org/10.1029/ 2005JD006318

45. C. Schaaf, Z. Wang, MCD43A4 MODIS Terra/Aqua Nadir BRDF-NBAR Daily L3 Global 500m v006, The Land Processes Distributed Active Archive Center (LP DAAC), NASA (2021). https://doi.org/10.5067/ MODIS/MCD43A4.006

46. R. Fu, L. Yin, W. Li, P.A. Arias, R.E. Dickinson, L. Huang, S. Chakraborty, K. Fernandes, B. Liebmann, R. Fisher, R.B. Myneni, Increased dry-season length over southern Amazonia in recent decades and its implication for future climate projection. Proc. Natl. Acad. Sci. USA 110(45), 18110-18115 (2013). https://doi.org/10.1073/ pnas. 1302584110

47. J.A. Marengo, J.C. Espinoza, Extreme seasonal droughts and floods in Amazonia: causes, trends and impacts. Int. J. Climatol. 36(3), 1033-1050 (2016). https://doi.org/10.1002/joc.4420

48. J.A. Marengo, C.A. Nobre, J. Tomasella, M.D. Oyama, G. Sampaio de Oliveira, R. de Oliveira, H. Camargo, L.M. Alves, I.F. Brown, The drought of Amazonia in 
2005. J. Clim. 21(3), 495-516 (2008). https://doi.org/ 10.1175/2007JCLI1600.1

49. J.C. Jiménez-Muñoz, C. Mattar, J. Barichivich, A. Santamaría-Artigas, K. Takahashi, Y. Malhi, J.A. Sobrino, G. van der Schrier, Record-breaking warming and extreme drought in the Amazon rainforest during the course of El Niño 2015-2016. Sci. Rep. 6(1), 33130 (2016). https://doi.org/10.1038/srep33130

50. A.P.M.A. Cunha, M. Zeri, K. Deusdará Leal, L. Costa, L.A. Cuartas, J.A. Marengo, J. Tomasella, R.M. Vieira, A.A. Barbosa, C. Cunningham, J.V. Cal Garcia, E. Broedel, R. Alvalá, G. Ribeiro-Neto, Extreme drought events over Brazil from 2011 to 2019. Atmosphere 10(11), 642 (2019). https://doi.org/10.3390/ atmos10110642

51. L.E.O.C. Aragão, Y. Malhi, N. Barbier, A. Lima, Y. Shimabukuro, L. Anderson, S. Saatchi, Interactions between rainfall, deforestation and fires during recent years in the Brazilian Amazonia. Philos. Trans. R. Soc. B 363(1498), 1779-1785 (2008). https://doi.org/ 10.1098/rstb.2007.0026

52. E.Y. Arima, P. Barreto, E. Araújo, B. Soares-Filho, Public policies can reduce tropical deforestation: lessons and challenges from Brazil. Land Use Policy 41, 465473 (2014). https://doi.org/10.1016/j.landusepol.2014. 06.026

53. K.A. Tasker, E.Y. Arima, Fire regimes in Amazonia: the relative roles of policy and precipitation. Anthropocene 14, 46-57 (2016). https://doi.org/10.1016/j. ancene.2016.06.001

54. L.E.O.C. Aragão, Y.E. Shimabukuro, The incidence of fire in Amazonian forests with implications for REDD. Science 328(5983), 1275-1278 (2010). https://doi.org/ 10.1126/science.1186925

55. J. Barlow, E. Berenguer, R. Carmenta, F. França, Clarifying Amazonia's burning crisis. Glob. Change Biol. 26(2), 319-321 (2020). https://doi.org/10.1111/ gcb. 14872

56. J.W. Veldman, F.E. Putz, Grass-dominated vegetation, not species-diverse natural savanna, replaces degraded tropical forests on the southern edge of the Amazon Basin. Biol. Conserv. 144(5), 1419-1429 (2011). https://doi.org/10.1016/j.biocon.2011.01.011

57. D.V. Silvério, P.M. Brando, J.K. Balch, F.E. Putz, D.C. Nepstad, C. Oliveira-Santos, M.M.C. Bustamante, Testing the Amazon savannization hypothesis: fire effects on invasion of a neotropical forest by native cerrado and exotic pasture grasses. Philos. Trans. R Soc. B Biol. Sci. 368(1619), 20120427 (2013). https://doi.org/10.1098/ rstb.2012.0427

58. J. Lizundia-Loiola, M.L. Pettinari, E. Chuvieco, Temporal anomalies in burned area trends: satellite estimations of the Amazonian 2019 fire crisis. Remote Sens. 12(1), 151 (2020). https://doi.org/10.3390/rs12010151

59. M.G. Fonseca, L.M. Alves, A.P.D. Aguiar, E. Arai, L.O. Anderson, T.M. Rosan, Y.E. Shimabukuro, L.E.O.C. de Aragão, Effects of climate and land-use change scenarios on fire probability during the 21st century in the Brazilian Amazon. Glob. Change Biol. 25(9), 2931-2946 (2019). https://doi.org/10.1111/gcb.14709

60. B. Montibeller, A. Kmoch, H. Virro, Ü. Mander, E. Uuemaa, Increasing fragmentation of forest cover in Brazil's
Legal Amazon from 2001 to 2017. Sci. Rep. 10, 5803 (2020). https://doi.org/10.1038/s41598-020-62591-x

61. M.V.F. Silveira, C.A. Petri, I.S. Broggio, G.O. Chagas, M.S. Macul, C.C.S.S. Leite, E.M.M. Ferrari, C.G.V. Amim, A.L.R. Freitas, A.Z.V. Motta, L.M.E. Carvalho, C.H.L. Silva Junior, L.O. Anderson, L.E.O.C. Aragão, Drivers of Fire Anomalies in the Brazilian Amazon: lessons Learned from the 2019 fire crisis. Land 9(12), 516 (2020). https://doi.org/10.3390/land9120516

62. W.T. Morgan, E. Darbyshire, D.V. Spracklen, P. Artaxo, H. Coe, Non-deforestation drivers of fires are increasingly important sources of aerosol and carbon dioxide emissions across Amazonia. Sci. Rep. 9(1), 16975 (2019). https://doi.org/10.1038/ s41598-019-53112-6

63. G.M. Pereira, S.E. da Silva Caumo, A. Grandis, E.Q.M. do Nascimento, A. Lima Correia, H.J. Barbosa, M.A. Marcondes, M.S. Buckeridge, P. de Castro Vasconcellos, Physical and chemical characterization of the 2019 "black rain" event in the Metropolitan Area of São Paulo. Braz. Atmos. Environ. 248, 118229 (2021). https://doi.org/10.1016/j.atmosenv.2021.118229

64. HRW (Human Rights Watch), IPAM (Amazon Environmental Research Institute) and IEPS (Institute for Health Policy Studies). The air is unbearable: Health impacts of deforestationrelated fires in the Brazilian Amazon (2020). https://www.hrw.org/report/2020/08/26/air-unbeara ble/health-impacts-deforestation-related-fires-brazilianamazon

65. L.E.O.C. Aragão, Y. Malhi, R.M. Roman-Cuesta, S. Saatchi, L.O. Anderson, Y.E. Shimabukuro, Spatial patterns and fire response of recent Amazonian droughts. Geophys. Res. Lett. 34(7), L07701 (2007). https://doi. org/10.1029/2006GL028946

66. Y. Chen, J.T. Randerson, D.C. Morton, R.S. DeFries, G.J. Collatz, P.S. Kasibhatla, L. Giglio, Y. Jin, M.E. Marlier, Forecasting fire season severity in South America using sea surface temperature anomalies. Science 334(6057), 787-791 (2011). https://doi.org/10.1126/ science.1209472

67. L. Chen, T. Li, B. Wang, L. Wang, Formation mechanism for 2015/16 Super El Niño. Sci. Rep. 7(1), 2975 (2017). https://doi.org/10.1038/s41598-017-02926-3

68. M.G. Fonseca, L.O. Anderson, E. Arai, Y.E. Shimabukuro, H.A.M. Xaud, M.R. Xaud, N. Madani, F.H. Wagner, L.E.O.C. Aragão, Climatic and anthropogenic drivers of northern Amazon fires during the 2015-2016 El Niño event. Ecol. Appl. 27(8), 2514-2527 (2017). https://doi.org/10.1002/eap.1628

69. C. Uhl, J.B. Kauffman, Deforestation, fire susceptibility, and potential tree responses to fire in the eastern Amazon. Ecology 71(2), 437-449 (1990). https://doi.org/10. $2307 / 1940299$

70. J. Barlow, C.A. Peres, Fire-mediated dieback and compositional cascade in an Amazonian forest. Philos. Trans. R. Soc. Lond. B Biol. Sci. 363(1498), 1787-1794 (2008). https://doi.org/10.1098/rstb.2007.0013

71. D. Nepstad, G. Carvalho, A.C. Barros, A. Alencar, J.P. Capobianco, J. Bishop, P. Moutinho, P. Lefebvre, U.L. Silva Jr., E. Prins, Road paving, fire regime feedbacks, and the future of Amazon forests. For. Ecol. 
Manag. 154(3), 395-407 (2001). https://doi.org/10. 1016/S0378-1127(01)00511-4

72. D.S. Alves, Space-time dynamics of deforestation in Brazilian Amazônia. Int. J. Remote Sens. 23(14), 2903-2908 (2002). https://doi.org/10.1080/ 01431160110096791

73. B. Soares-Filho, A. Alencar, D. Nepstad, G. Cerqueira, M.C. Vera Diaz, S. Rivero, L. Solórzano, E. Voll, Simulating the response of land-cover changes to road paving and governance along a major Amazon highway: the Santarém-Cuiabá corridor. Glob. Change Biol. 10(5), 745-764 (2004). https://doi.org/10.1111/j. 1529-8817.2003.00769.x

74. P.M. Fearnside, P.M.L. de Alencastro Graça, BR-319: Brazil's Manaus-Porto Velho Highway and the potential impact of linking the Arc of Deforestation to Central Amazonia. Environ. Manag. 38(5), 705-716 (2006). https://doi.org/10.1007/s00267-005-0295-y

75. P.M. Fearnside, Brazil's Cuiabá- Santarém (BR-163) Highway: the environmental cost of paving a soybean corridor through the Amazon. Environ. Manag. 39(5), 601 (2007). https://doi.org/10.1007/s00267-006-0149-2

76. D. Armenteras, J.S. Barreto, K. Tabor, R. MolownyHoras, J. Retana, Changing patterns of fire occurrence in proximity to forest edges, roads and rivers between NW Amazonian countries. Biogeosciences 14(11), 27552765 (2017). https://doi.org/10.5194/bg-14-2755-2017

77. C.P. Barber, M.A. Cochrane, C.M. Souza, W.F. Laurance, Roads, deforestation, and the mitigating effect of protected areas in the Amazon. Biol. Conserv. 177, 203-209 (2014). https://doi.org/10.1016/j.biocon.2014. 07.004
78. P.R.R. Rochedo, B. Soares-Filho, R. Schaeffer, E. Viola, A. Szklo, A.F.P. Lucena, A. Koberle, J.L. Davis, R. Rajão, R. Rathmann, The threat of political bargaining to climate mitigation in Brazil. Nat. Clim. Change 8, 695-698 (2018). https://doi.org/10.1038/ s41558-018-0213-y

79. Y. Sencébé, F. Pinton, A.A. Cazella, On the unequal coexistence of agrifood systems in Brazil. Rev. Agric. Food Environ. Stud. 101, 191-212 (2020). https://doi. org/10.1007/s41130-020-00099-8

80. P.M. Brando, B. Soares-Filho, L. Rodrigues, A. Assunção, D. Morton, D. Tuchschneider, E.C.M. Fernandes, M.N. Macedo, U. Oliveira, M.T. Coe, The gathering firestorm in southern Amazonia. Sci. Adv. 6(2), eaay1632 (2020). https://doi.org/10.1126/sciadv. aay 1632

81. Y. Le Page, D. Oom, J.M.N. Silva, P. Jönsson, J.M.C. Pereira, Seasonality of vegetation fires as modified by human action: observing the deviation from eco-climatic fire regimes. Glob. Ecol. Biogeogr. 19, 575-588 (2010). https://doi.org/10.1111/j.1466-8238.2010.00525.x

82. A. Staal, B.M. Flores, A.P.D. Aguiar, J.H.C. Bosmans, I. Fetzer, O.A. Tuinenburg, Feedback between drought and deforestation in the Amazon. Environ. Res. Lett. 15(4), 044024 (2020). https://doi.org/10.1088/ 1748-9326/ab738e

83. D.C. Morton, R.S. Defries, J.T. Randerson, L. Giglio, W. Schroeder, G.R. Van der Werf, Agricultural intensification increases deforestation fire activity in Amazonia. Glob. Change Biol. 14, 2262-2275 (2008). https:// doi.org/10.1111/j.1365-2486.2008.01652.x 